\title{
The Reflected Mythological Patterns on Researchers' Journey through Literacy Narratives
}

\author{
Mohammad Sugeng Rahman Hakim ${ }^{1}$, Pratiwi Retnaningdyah ${ }^{2}$, Ali Mustofa ${ }^{3}$ \\ Postgraduate Program, Universitas Negeri Surabaya, Jl. Ketintang No.30, Ketintang, Gayungan, Surabaya, \\ East Java 60231 \\ Moch.17070835063@mhs.unesa.ac.id¹,pratiwiretnaningdyah@unesa.ac.id², alimustofa@unesa.ac.id³
}

\begin{abstract}
This paper aims to provide a heroism mythological reflection on the journey of researchers. This study uses the qualitative case study to obtain the comprehension of researchers' metaphor journeys through Monomyth on their research experiences. The documentary analysis is used in this qualitative study with the reflexive narrative because the reflection on experience can help the reader to gain insight into the researcher and their approach during the journey. 15 researcher's literacy narratives chosen in this study which consists of 8 published literacy narratives and 7 literacy narratives task from participants. Research itself often considered as a journey that extends the existing knowledge and also develops new knowledge of the researcher while wandering in the wilderness of knowledge. Along the way, the researchers with their literacy narratives in this study unconsciously have a similar mythical pattern story as like as the mythical heroes which Campbell (1949) term it as 'Monomyth' pattern. The result presented in this paper may facilitate the literate improvements in which to motivate, to help the novice researcher to understand their own hero's journey and to educate them about the stages that they will experience such as their new transition of conducting their new research.
\end{abstract}

Keywords: Monomyth; Mythology; Heroism; Research Journey; Literacy Narrative DOI: 10.15642/NOBEL.2019.10.1.15-31

Literature is commonly represented 'heroism which inseparable from human being's lives through stories or literary works. In heroism, each hero has a journey. Campbell (1949) explains that each journey has its own transition process where the main characters change from their status quo or save zone and jump into unfamiliar special word, then return to their ordinary world. Since literary works are the mirror of human life, the process of the hero's transition during the journey also reflects humankind. As a human, researchers also have a journey while wandering in the wilderness of research jungle. The research itself often considered as a journey (McCulloch, 2013), a journey that extends existing knowledge and also develops new knowledge (Trafford \& Leshem, 2009; Wellington, 2010). Along the way, they unconsciously have a similar mythical pattern story as like as the mythical and modern heroes have which Campbell (1949) term it as 'Monomyth' or ‘The Hero's Journey' pattern.

Many studies explore the changes or metaphors of the Hero's Journey reflected through humans' life in narratives whether visual or textual. But, reflecting someone's academic experiences to the hero's journey consume a lot of times and such a largely novel. So, it is 
essential to limit the transition of the subjects' experience in a specific story of their life. Harwell, Comstedt, \& Roberts, 1997; Follo, 2002; Goldstein, 2005; Randles, 2012; Seary \& Willans, 2004; Georgas, Regalado, \& Burge, 2017 presented a comprehensive review of how the Monomyth concept and analyzed their students' experiences while encountered problems during the process of their study and proceeding stage. Their articles summarize that this scope of studies has been previously accepted that the Hero's Journey also reflects on the educational range experiences.

Based on the previous studies, the writer wants to reflect and compare the researchers journey specifically to the young and junior researchers' experiences with the heroes' journey of literary works or stories represented in Monomyth theory. Since the data must have a plot, a theme, character and also must share the subjects' experience, literacy narrative in the form of written experience is an appropriate approach which supports this research. Literacy narrative nowadays is a popular way or term for people to share their connection with the literary world such as speaking, reading, and writing or sharing their experience about specific competence they learn. It gives people a chance to write it as a personal story. They can develop a reflective understanding of their first experience when they are forged to be literate while conducting research on their life.

\section{REVIEW OF LITERATURE}

\section{Hero's Journey through Literature and Education}

Campbell as the one who coined the theory of Hero's journey (1949) explores a series of the interconnected stage in the universe of legends, folktales, myths, literature and found that they have a similar pattern where their heroes or the main characters always begin their stories in a stage of unknowing or status quo. This stage is disrupted by some events and leads the hero into the decision or call to adventure on a journey where the main characters encounter their trials and test. If those heroes can conquer their problems and fears, they come back to their ordinary world with "the power to bestow boons".

The monomyth is also a study about universal patterns, symbols or archetypal images which reveal themselves in our dreams and are capable of giving us knowledge and awareness when interpreted in light of their meaning to the individual. "The function of myth is to put a man in accord with nature." (Campbell, 1949). Since this research explores and compares the mythology phenomenon patterns on the research journey of graduate students or researchers, there are three Acts of the Hero's Journey based on what Campbell said; separation, Initiation, and Return will provide the paradigm in which to view a contemporary case study. 
The renowned screenwriter Christopher Vogler (2007) praises the Hero's Journey theory as "nothing less than a handbook for life, a complete instruction manual in the art of being human". It means that if we posit that literary works such as myths, folklore, and legends explained in Campbell's concepts as the reflection of human life, we also can reflect the concept of Hero's journey to arm our new researcher with a map of their own 'Hero's journey' such as like what Bloom, Hutson \& He (2008) suggests in their article. They charged as the advisor by helping their students become more aware of their lifelong journey of learning and personal development. They compare their experiences as like as their own 'heroic' literary story which mirrors their first transition experiences as college students into a researcher or from someone who knows nothing to someone who knows things based on Campbell's “Separation, Initiation, and Returns” in Hero's Journey stages.

This study intends to explore the researchers'journey phenomenon that unconsciously follows the concepts of Campbell's Monomyth. The writer uses the qualitative case study to obtain the comprehension of researchers' metaphor journeys and literacy sponsors through Monomyth on their research experiences. The documentary analysis is used with the reflexive narrative because the reflection on experience can help the reader to gain insight into the researcher and their approach (Creswell, 2010). This research affords the writer the opportunity to understand how individuals interpret their research experiences through their written stories, construct their worlds on it, and apply to mean to their experiences in a naturalistic setting (Creswell, 2007; Merriam, 2009).

To maintain the naturalistic setting of the data, the writer chose the existed or published online literacy narratives data without any control of the subjects' experience. The data were also supported by literacy narrative tasks given to 10 graduate students who are acquaintances to the writer of this study. The data were collected through an online search engine with the keyword "My Research Journey". Through the keywords there found the researchers who already shared and published the reflection about their research journey in the form of a journal article, and blog. Different from the author of published literacy narratives, the names of participants who willingly write the research journey task are given pseudonym name to the participant's code ethics.

Since the data overflowed through the Google search engine, I set purposeful selection and criteria to reveal the required data in the research. Firstly, the subjects of this study are researchers which are limited only for young to the junior researcher. Based on Eurodoc (2017), Young Researcher in this study is a term which defines researchers in the first 10 years of their research activity or researcher who is still training to conduct research whether 
in university or equivalent of higher education who has not yet obtained a doctoral degree. Junior Researcher is a term which refers to researchers who have been graduated or awarded a doctoral degree and not yet fully engaged conduct independent research whether in academia, private or in the public sector. Secondly, the literacy narratives collected through the search engine must have plot, theme, character, setting or even moral value. A literacy narratives essay is not just an interesting story about an experience. It also guides the reader towards an insight by showing what they learned from their research experience.

\section{DISCUSSIONS OF MAIN THEMES}

\section{Reflected Monomyth on researchers' research journey}

Based on Campbell (1949), a hero is someone who has given his or her life to something bigger than oneself. This chapter analyzes the growth and passage of the researchers during the process of their research journey based on their written experiences. The reflected Hero's Journey requires a separation from the comfortable zone, known world, and an initiation into a new level of awareness, skill, and responsibility, and then a return home. The writer will provide analysis of each Act of the researcher's journey based on their literacy narratives data.

The following analysis is presented through reflective narratives based on Vogler's table of Monomyth as follows; the first Act is Separation which includes stages "The Ordinary World, Call to Adventure, Refusal of the Call, Meeting with the Mentor, Crossing the First Threshold", the second Act is Initiation which includes "Tests, Allies, and Enemies, Approach the Inmost Cave (crossing the second threshold), The Ordeal, Reward," and the last Act is Return which includes "The Road Back, Resurrection, Return with the Elixir" (Vogler, 2007, p. 9)

\section{The Ordinary World}

In literary works, many stories, myths, legends are journeys which take their protagonists or heroes to Special Worlds. The authors mostly begin by establishing the main characters who live in Ordinary Worlds as a baseline of comparison to the new inexperience or the Special World. This World is only special if we can see it in contrast to the comparison of the hero's everyday world.

The Ordinary World has a meaning of home base or the background of the hero. In this context, the Ordinary World means the world which the researchers who become the subject of this research are familiar with. The difference between the two worlds is not represented by the terms 'muggle and magical', 'earth and space', 'village and city' or even 'dark and light', but by the life around the characters and the transformation or metaphor that happen inside 
the characters, like from no one to someone, zero to the hero or from the man who knows nothing become the knowledgeable man.

Some researchers are found to start their ordinary literacy narratives journey from their childhood background, for instance, a literacy narrative from a Ph.D. dissertation written by Carrim (2012). She writes a reflective research journey in chapter 9. She begins her reflective story from her childhood on how she lives with her family "I was raised in a small segregated Indian township called Primedia in Brits during the apartheid era...Most of my childhood was spent studying, and during the holidays we would assist my mother in spring cleaning the house" (p.296).

Carrim writes her childhood story to reveal what motivated her to board on her research topic which later will become her Call to research. In her Ordinary World, specifically in her childhood community, she writes her traditional-minded "feminine" society like how a girl should not have a high academic profile like what her mother thought that "Indian parents aimed to marry their daughters at an early age and did not pay heed to educate their daughters" (297). Luckily, her father has a different opinion with their traditional society. He allowed and encouraged his little girl to continued her studies. Later on, when she graduated and started working as a lecturer at a University, she already got used to the "feminine" norms of her society, even state that "For me, this cultural norm is a blessing, as I would have been very lonely living away from my family". The "blessing" word in her statement shows how she admits and takes a positive value of her traditional-minded norms.

Another literacy narrative is taken from the task which the writer gives to his acquaintances who are willing to be participants in writing the literacy narrative about their research journey. One of the participants is named Jacklyn (pseudonym). During his college years, Jacklyn is an active scholar in his campus organization. In his literacy narratives, he writes that:

The fourth year was a pretty hard time I faced and makes me stressful. It happens because of the issue of my final research that never ends. The waiting process of my supervisor news about my revision makes me even more stressed since my body get used to doing a lot of productive things. The terms of waiting and patience is not my habit.

Jacklyn spends almost three years of his college time in a student organization. When doing his research, his 'the Ordinary World', in this case, his organization activity, must collide and force him to learn about patience. 
Not all the literacy narratives examined in this study write the ordinary world in their writing experiences. However, this stage unconsciously occurred in their lives before. In this case, The Ordinary World in one sense is the specifically last place or state of the researchers (students, young researcher or junior researcher) before the adventure of researches begins. Previously, they pass through a succession of Special Worlds which slowly become ordinary as we get used to them (Vogler, 2007), like how Carrim get used for her traditional-minded family and Jacklyn with his common productive 'World'. They evolve from strange, foreign territory into familiar bases from which to launch a drive into the next 'Call of the Adventure' to new Special World.

\section{Call of the Adventure}

Vogler theory of screenwriting mythological patterns acknowledges the Call to Adventure of Monomyth as the initiating event, or incident which become the catalyst or the trigger of the main characters' story. Some events are important to roll the story forward once the protagonist finished introducing his or her ordinary world.

Previously, Carrim (2012) introduces herself in her reflective journey that she already gets used to her daily life with the feminine norm of her society. As the symbolical of the Call, she writes that "My research interest was driven by my own career as a manager" (p.300). She wonders whether the other Indian women manager in South African have similar problems in the term of their feminine mobility in their family and office, she writes "I was very curious to find out about the role of the Indian community and family in the lives of other Indian women managers and how this influenced their upward mobility."(p.301). This statement expresses that Carrim's interest provokes her curiosity which represents the 'Call' of her research journey.

Another analyzed literacy narrative of a research journey is taken from a Ph.D. dissertation written by Retnaningdyah (2015). On her research, she examines how and why digital literacy in this modern era is important to the activism of Indonesian migrant Domestic Workers (IDW) in Hong Kong. Her research study is chosen as one of the literacy narratives in this study since she uniquely starts her research in the narrative style of writing. Her research topic starts with her personal experience around 2005 when she first encountered and realized how hard the world of foreign domestic workers are. With all strict regulations, they seem afraid to express their opinions and rights. Following this experience, the curiosity and the 'Call' to write this topic happens when later on she learned that many other IDWs in Hong Kong embrace the digital literacy world to speak out their personal experience. 
The author of the story commonly makes the stage of 'The Call to Adventure' by introducing a message or a messenger to the hero represented as mythological archetype character of Herald (Vogler, 2007). The symbolization of the mythological Herald character in the story can be physically or spiritually. Physically, the herald itself can symbolize in anything inside the story such as an actual person or event like a declaration of war, or the arrival of a letter to attend Hogwarts magical school in Harry Potter and The Sorcerer's Stone. Spiritually, the herald Call that offers the adventure to the hero may simply be a messenger from the unconscious mind, like dreams, visions, fantasies, prophecy or a conscious stirring will of the hero's messenger like ideas, past experience, wisdom or even question like what most young and junior researcher in this study look for as their research question.

The symbolical 'Messenger' or 'Herald' mostly found in this study are in the form of curiosity of the researchers. However, few of the researchers' literacy narratives taken from the task write that their journeys are 'Called' by conducting and assisting their mentor's research. The force of coincidental occurrences of events, ideas, or someone else word can also symbolize the herald who gives the message to the hero. This force can draw the researcher's attention to act, wonder, and answer the 'Call of the Adventure' (Vogler, 2007).

The Call to Adventure in some stories may come when their heroes are simply running out of options. the hero option is limited through this call whether he dies or challenges the call immediately. He or she needs to commit to the adventure whether they like it or not. Some researchers have this kind of experiences when they are still in scholar progress to achieve a graduate degree. They are forced to take the adventure of research jungle because of the lack of time and money to extend their study or even their learning period is in the edge of time.

\section{Refusal of The Call}

It is natural as human or heroes to have refusal act for the first time the Call comes. They refuse to the Call by stating a series of weak excuses to elude or delay their inevitable Call which may shake their ordinary comfortable zone. Even though the hero's life is not actually comfortable, they already used to live such a life before and are afraid to make it worse. In popular culture story, we can find in the early story that Harry Potter doesn't believe that he can be a real wizard. In Star Wars, Luke Skywalker is reluctant to accept Obi-Wan's offer. Frodo in Lord of the Ring is reluctant to leave the ordinary life he knows.

While many heroes express a refusal at this stage, the others don't hesitate to jump at the chance and answer the Call. Some of them are the heroes that are forced to jump without 
any option or choice left. It is either to jump or to die (Vogler, 2007). This kind of situation might happen in a research journey when the young researchers specifically final-year students are already at the edge of their studies terms. Some others, like most of the researchers found in this study, are classified as what Vogler terms as 'Willing Heroes' who have accepted willingly or sought the Call of the Adventure, although it does cover out the possibility of researcher's journey data out there who reject the 'Call' of research because of the fear of failure or other reasons. Most of the researchers collected through the literacy narratives analyzed in this study are pushed and called by their interest and curiosity about certain problem and topic.

However, even though the heroes didn't refuse for the Call, the doubt and fear which symbolizes the Refusal of the Call will come to a hero anywhere in the story. The Refusal can come from other characters as well as events. They will express the fear and give the warning to the protagonist about what may happen on the road of the journey ahead. The fear and warning in this researchers' journey can be represented by their ignorance, unpreparedness, lack of knowledge about the tools to challenge and conquer their research topic like what Debbie (2017) writes "one of the most difficult aspects of social research is choosing an appropriate methodology" (p.2).

While the hero needs a sword, shield, and bow to slain the dragon, the researchers need specific methodology, theory, and literature review to support them and finish the quest of their research topic. Shawn Wilson (2008) argues that methodology is "part of the paradigm that guides the research process". And theory provides a vocabulary and discourse to describe what the researchers think (McCotter, 2001). Methodology and theory for the researchers are perhaps best described as the map of where knowledge or treasures are hidden. It is of little or no use if the researchers do not know how to use the map wisely.

Refusal of the Call can also be a chance or the opportunity to redirect the main characters' focus of their journey. In a literacy narrative task written by the participants named Natalia (pseudonym), she told that in her researcher's journey, her supervisor refuses her submitted topic because of the difficulties of data and the lack of knowledge. This kind of refusal gives some kinds of advice or redirection to the young researchers to change or shift their research topic, research question or theory and make them more focus on their goal.

As the beginners in the jungle of research, many young researchers might hesitate at the threshold of their ordinary common world and special world. They need someone who helps them from the journey ahead, like a wise man who gives them a protective shield, the sword of knowledge like methodology, theory, map of information of the literature review to prepare 
them before they jump to the special world. This archetype wise man is representing the energy or the symbol of the next phase, "Meeting with the Mentor"

\section{Meeting with the Mentor}

Refusal of the Call is not always bad at certain meaning. The heroes sometimes refuse the Call when they are still not ready until they had time to prepare the challenge of the unknown zone that lies in Special world. During the set-up process of the Hero, Vogler (2007) stated that "preparation might be done with the help of the wise, protective figure of the Mentor, who provides many services to the hero include protecting, guiding, teaching, testing, training and providing magical gift" to overcome the fear and start the adventure.

In research journey, the undebatable and proper character that can be easily found to symbolize the 'Mentor' is the supervisor. In academic research, either thesis or dissertation, we can commonly find a short literacy narrative of the researchers who express their gratitude for their supervisor in the 'Acknowledgements' section, for instance:

First and foremost, I would like to express my sincerest gratitude to my primary supervisor, Associate Professor Francesca Martin, who has tremendously provided me with the greatest assistance and support possible... I owe her my deepest gratitude for shaping this thesis to this current direction (Retnaningdyah, 2015: 5).

Similar to Retnaningdyah (2015), although not in acknowledgment form, almost all of researchers in their literacy narratives tell about how they were helped and aided by their supervisor.

Mackenzie and Lorraine (2009), whose research is one of the published literacy narratives in form of journal, writes their experienced journey as they worked as supervisee and supervisor through the several stages of the supervisee's doctoral research and thesis writing. Mackenzie writes that his "supervisor advised that the journey should begin with a thorough review of all the literature about the proposed destination based upon the experiences of previous travelers (researchers)" (p. 51). Searching the literature reviews takes a long consuming, boring, and sometimes frustrating time. But, when they reaches their limits "My frustrations were taken to my supervisor, who patiently listened and advised and eventually my journey began in earnest." This statement proves that this archetype character of Mentor only provides aid, suggestion, advice, and supply for the hero when the hero needs and does not accompany the hero during the quest (Propp, 1979).

'Meeting with the Mentor' stage can symbolize anything inside the story even though there is no actual character that is specifically showed as Mentor character. The young 
researcher which becomes the protagonist in the research jungle always needs to make contacts with some sources of knowledge or wisdom before jumping to their quest. When they cannot find the physical 'Mentor', they will try to find a former adventurer who has the similar experienced problem or former records of previous research, literature reviews, and artifact of knowledge or simply look inside themselves for wisdom experienced they have in their previous adventure. McCotter (2001), who writes one of published literacy narratives analyzed in this study, argues that "one of the first struggles on my journey was deciding how to use theory in my research". Even with class discussion and reading a lot of literature review the theory is still enigmatic for him. Later on, "After reading a piece by Laurel Richardson about the metaphors commonly used in discussing theory", he began to consider the theory as a map that guides her decisions and gives direction as he tries to find his way during the research journey.

\section{Crossing the First Threshold}

The Call of Adventure has been heard. Now the researchers have already well prepared to take a challenge and conduct their research. However, the most critical moment of Act One still remains. As the researchers approach the threshold of the two World, they commonly encounter a 'Threshold Guardian' who blocks or hinders their way to the Special world. This mythological character function like the Gate Keeper of the Special world. The Keeper won't allow anyone who is not worthy enough to pass the Gate. The Hero needs to be tested to pass the Keeper of the Special World in Act Two.

This archetype does not only pop up to block or test the Hero in the early story. The Keeper may appear at any point in a story, but mostly they "cluster around the doorways, gates, and narrow passages of threshold crossings" (Vogler, p129). The purpose of the test or the symbolical Keeper at Crossing the First Threshold is to prove that the Hero is willing to commits wholeheartedly to the adventure. Murphy and Wibberley (2016), in their published literacy narratives, give a good example where the researchers are tested by their 'Mentor' or supervisor which also symbolizes the threshold guardian archetype character.

Here, at times, conflicts happened, with debates and discussions related to the best way forward in relation to the style and manner of research approach. My supervisors would adopt differing viewpoints, perhaps playing Devil's advocate, but presenting me with the decision on how to proceed. (Murphy \& Wibberley, 2016: 3)

It's unfortunate that the other published literacy narratives besides Murphy and Wibberley (2016) did not state specifically about this stage where their research topic and knowledge was tested, measured, and assured by the threshold guardian. This might happen 
because the author of published literacy narratives is not bounded or tasked to tell a specific story of their research journey.

However, the other participants' literacy narratives tasked by the writer were asked to write this specific experience of their research journey. Previously, Natalia (pseudonym) had a debate and got a refusal from her supervisor about her research topic. Similar to her, because of the lack of knowledge, The other participants which in this study represented by Afandi (pseudonym) also need to redirect or shift their research topic, research question or theory, "in my proposal seminar, the examiner and supervisor ask me a lot of question that make me confused and finally, it ends with many revisions for my proposal". This statement represents most of the young researcher which in other words are still in students. They need to pass the seminar proposal or comprehension examination before continuing their researches.

\section{Tests, Allies, And Enemies}

In this new Special World, the test, challenges, and trials are the tools of adjustment for heroes meant to prepare them for their greatest ordeal ahead. The tests and challenges in this phase are sometimes difficult for the heroes, but still are in reasonable limits. However, as all young and junior researchers inevitably find out later on, no matter how prepared and adjusted they are to this new inexperience special world, even when they think they have covered everything in their theoretical understandings and data gathering instruments, "nothing can quite prepare you for the reality of the research experience" said Debbie in her literacy narrative (2017). If in the Act One or 'Separation' phase the researchers faced a series of entrance exams, in Act Two or 'Initiation' phase the researchers will be faced with a series of quizzes, questions, and trials which aims to sharpen the researchers' skills.

The trials can be any things during the research journey with unlimited internal and external reasons or factors, for example, the difficulties to trust and get the valid data from the interviewed participants (Hohaia, 2017; Carrim, 2012), once again feeling doubt, getting lost in the wilderness of data analysis, theory, and literature review (Mackenzie \& Lorraine, 2009; McCotter, 2001), dissent with supervisee (Murphy \& Wibberley, 2016) the freedom of conducting research weakens and slows down due to illness (Retnaningdyah, 2015), or even losing four close family member in a year while conducting research (Carrim, 2012).

During the hard times of the journey to the special word, it is natural for a human to spend his time to seek and share his or her problems to someone who can be trusted and relied on as his 'Allies'. Vogler (2007) argues in his book that the act of choosing the 'Allies' and 'Enemies' symbolizes as one of the tests and trials for the hero "examining if the hero is a 
good judge of character." (p.137). In other terms, this can be explained as the tests and trials to train the researchers' ability and wisdom in deciding which one is good and bad for them.

Spiritually, the 'Allies' and 'Enemies' archetype characters give the hero's thought that he is not alone on his journey. In Carrim literacy narratives (2012), the participants can act as 'Allies' who are good, understanding and willingly help the researcher or even rude as 'Enemies' who like to act as they please during the process of interview to collect the data. A mentor can also become the researchers' 'Allies' or 'Enemies' depend on their contribution, whether they act as helper every time the hero needs (Mackenzie \&Lorraine , 2009) or act as hinder who test the readiness and knowledge of the researcher (McCulloch, 2013). But, these two mythical archetypes depend on the good or bad perception of the researchers themselves and how they deal with it. Books, theory, literary reviews written by the former researcher are also things that help researchers represent symbolical allies (McCotter, 2001).

\section{Approach the Inmost Cave}

Previously, the heroes are having an adjustment in their new Special World. Now it is time for the protagonist to seek deeper to the research jungle. Vogler (2007) illustrated this stage in a line; the researchers have already passed the intermediate zone "between the border and the very center of the Hero's Journey" (p.222). Along the way in approaching the center of the jungle (ordeal stage), this stage can represent many things like an actual danger, terrible place or hero's inner conflict which has not been faced until now.

This stage is similar to the stage of 'Crossing the Threshold Guardian'. In this study, because of the nature of the published literacy narratives, many researchers did not state specifically about the stage or story when they are preparing or 'approaching' their greatest fear. In approaching the inmost cave, based on Jacklyn's and others' literacy narratives, they take their times to make plans, study, reorganize, reconnaissance, relearn, reread, and fortify their minds with more books and knowledge, or even have a last laugh and party before they jump to the main scene called 'The Ordeal'.

\section{The Ordeal}

This time the heroes stand in the inmost cave at the deepest jungle, facing their greatest fearsome enemies and challenge. In myths, Campbell's so-called 'Ordeal' intrinsically is a stage of an "expansion of consciousness for the hero" (1949, p. 228). Similar to the approach, this stage may be a symbolical, mental or physical dangerous crisis that the main character needs to conquer to continue the journey.

The Ordeal can be interpreted as the stage where the heroes or the researchers face their greatest fear (Vogler, 2007). For most people, the greatest fear might be symbolized as death. 
However, it can also represent many things in the story such as the failure of the test, the end of a relationship, losing an important match, witnessing and bereaving for the loved one. Based on the literacy narratives written by Jacklyn et.al., as novice researchers who are in college, Their first goal in conducting the research is to graduate and get a diploma or special acknowledgment besides their curiosity for the research topic. Thesis or dissertation is a 'high wall' they need to pass to get that treasure. To pass the 'wall', they need to be tested again in their final examination. Vogler explains Campbell's terms that the 'Ordeal' is "the metaphor process of consciousness for the hero. The hero gains their enlightenment through his decision and actions" (2007, p. 228).

\section{Reward}

After surviving the final exam and encounter the 'Ordeal', it is a triumph time for the researchers to seize the sword of victory, celebrate and take the hidden treasure. Symbolically, the researchers are reborn into the new realm. The aftermath of the ordeal has many shapes and purposes. The heroes gained 'Reward' or the 'Ultimate Boon'. The Boon, in this case, can be the hero's blessing in the form of wisdom, magical elixir, knowledge, treasure, power, or even special recognition after surviving the great ordeal or symbolical death. Natalia writes in her literacy task that "I feel really really happy when my examiners and supervisors said congratulation for my new M.Ed. title"

Since all the problems or 'Ordeal' phase has passed, Murphy (2016) tells that when he looked back at the beginning his ordinary world, and compared his thoughts to now, "I am a different person with a developing new academic identity." This self-realization may stay only for a while, but for that moment they see themselves clearly about how foolish and stubborn they are all this time. In this stage, the heroes' insight might be of a deeper and wiser than before. Vogler argues that they sometimes experience "profound self-realization after tricking death" (p.181). The researchers see their self-potential, spiritually, and fully about who they are and how they got to this point.

\section{The Road Back}

Once the 'Reward' and the lessons of the quest or great 'Ordeal' have been succeeded and celebrated, officially the hero moves to the Act Three of the Hero's journey. In this stage of 'The Road Back', Vogler (2007) explains that the heroes “must decide whether to stay in the special world or go back to the ordinary world" (p.190).

The term 'The Road Back' represents the resolve of the heroes to return to the 'Ordinary World' and implement the lessons that they learned in the 'Special World'. As this research journey began to come to an inevitable end, the young and junior researchers who 
have completed their studies must come back to their community to apply the knowledge that they learn from the college. However, to leave the special word, this can be far from easy to some researchers.

Based on the literacy narrative task, Retno (pseudonym) writes her unpreparedness feeling that "I feel afraid to leave my college life, since I'm not ready to join the unemployment of the society". In another literacy narrative written by Mackenzie (2009), he shared that during that time, he felt excited about the opportunity to share the treasure that he got from his studies to the society, but he also felt sad that the journey had ended because of the unexplored jungle of knowledge which will be left behind (p.54). But no matter how heroes determine to try to stay in the Special World, "the Special World somehow will push the heroes back to the Ordinary World" (Vogler, 2007: 187) to tell others about the boon, knowledge and share the treasure or their magical elixir they have won.

\section{Resurrection}

The next stage before the researchers officially return to their ordinary world is 'Resurrection' stage. Vogler (2007) describes that the objective of resurrection is to create "the feeling of resurrection with a corresponding lift of relief" (p.198). When researchers come to the special world, they need to adjust their old self to the new research world. In the process of return, they need to readjust and resurrect their new self to the ordinary world. Simply, the resurrection stage is another additional phase of death and rebirth, similar to the Supreme Ordeal but subtly different. Vogler also states that the hero must use all knowledge and skills he got during the journey and transformed it into a "new being with new insights".

Unfortunately, since the 'Resurrection' is the stage when the researchers already return to their community, most researchers in their literacy narratives did not state specifically about the transition struggle when they come back to their old community. However, the outline of 'resurrection' pattern of the research journey and 'Monomyth' can be illustrated when the researchers 'Return' from their research journey. They need to shed the personality or readjust and build a new one that is suitable for their community in the ordinary world. They cannot impose their elixir of knowledge to people who know nothing about it. They should sacrifice their ego and "be passionate, positive, and persevere". "This is what I have learned through my research journey," wrote Hohaia (2017), to accept the lack of knowledge of the community and search the best way to approach and teach them. The resurrection should reflect the best parts of the old selves and the lessons learned along the way.

\section{Return with The Elixir}


Having survived through the greatest fear and all the ordeals, the researchers return to their common world, go home, or continue their journey to the advanced level. They always proceed with a sense that they are beginning a new life. This new ordinary world will be forever different from their previous one because of the journey they just traveled. Retnaningdyah (2015), in returning to her new common world in Indonesia, thought how she could apply, share and teach her symbolic Elixir of knowledge and theory she learned from the previous journey to the society as she writes "I am beginning to immerse myself in a number of community-based literacy activism" (p.234).

From the literacy narratives of the research journey, the writer can find easily 'Return with the Elixir' stage in the conclusion section. In Debbie's conclusion, she hoped that after sharing her struggle in her research journey "this will assist other researchers to reflect on some of the relationships and experiences they have encountered during the conduct of their work" (2017: 45). Similar to Debbie's writing some of the analyzed researchers write and give some advices, hoping for the reader who will be or has already interested in the similar path of the journey.

The enlightenment from the rebirth and resurrection stage makes the hero understands more about the two 'Worlds'. The first world is where the magical and temptation of knowledge rest. This is their previous special world where students, researchers, and scholars gather, share and debate their opinion freely. The second world is the researchers' new 'Ordinary World' where the common people do not know and care about the struggle, effort, and suffering of the researchers to get the specific knowledge that later will be used by them in society. Sometimes the old world or 'new ordinary world' community do not want the elixir carried by the researcher because of the difficulty of the elixir to understand. Apart from difficulties of sharing their elixir, the desire to share and teach knowledge they had learned before made the researcher transformed into a what Campbell term as 'Master of the two World' or simply from the hero of their own journey become the mentor of other's journey.

\section{CONCLUSION}

The writer found that young and junior researchers in their research journey unconsciously followed the Campbell's mythological 'separation, initiation, and return' pattern of 'Monomyth' through their literacy narratives. However, it does not fully follow the exact stages or phases of the three Acts because of the nature of the data which are not bound the author to write specific stories in their research journeys. Based on the result, although with 
all the differences of background, topic, the internal and external problems during the research journey, the researchers have similar pattern as like as heroes in a literary work.

Comparable to the unknowing special world Monomyth concept about the heroism pattern, the researchers also undergo their own transition process from a scholar into a researcher or from a researcher into a Mentor. Heroes take journeys, encounter dragons and uncover treasures. Similarly, in new researchers' symbolical journey, the dragons are the research problems or questions, and their treasure is new insights and knowledge. They transferred into a new, inexperienced world when they start the research journey, by jumping into and analyzing unanswered question research. When their research journeys end, they return to teach and share their elixir of knowledge to their community.

The result presented in this research may also facilitate the literate improvements in which to motivate, to help new or novice researcher to understand their own Hero's journey and even to mentor the others about the stages or the transition process while conducting their new research.This result provides a good starting point for discussion and further research about the effectiveness of writing literacy narratives for researchers as their self-reflection and sharing medium of their research journey.

\section{REFERENCES}

Bloom, J. K., Hutson, B. L., \& He, Y. (2008). The appreciative advising revolution. Champaign.

Campbell, J. (1949). The hero with a thousand faces. Chicago: New World Library.

Carrim, N. M. (2012). “Who am I?”- South african indian women managers' struggle for identity: escaping the ubiquitous cage. Pretoria: University of Pretoria.

Creswell, J. W. (2010). Mapping the developing landscape of mixed methods research. SAGE handbook of mixed methods in social \& behavioral research, 2, 45-68.

Follo, G. (2002). A hero's journey: Young women among males in forestry education. Journal of Rural Studies , 18, 293-306.

Georgas, H., Regalado, M., \& Burge, M. (2017). Choose your own adventure: The hero's journey and the research process. Journal of Leading Transformation , 121-131.

Goldstein, L. S. (2005). Becoming a teacher as a hero's journey: Using metaphor in preservice teacher education. Teacher Education Quarterly 32 , 7-24.

Harwell, R., Comstedt, T., \& Roberts , N. (1997). A Hero's journey: A freshman orientation challenge course program, in Deeply Rooted, Branching Out. 25th Annual AEE International Conference (pp. 81-88). New York: L-Jay Fine. 
Hohaia, D. (2017). Opening the dialogue: Reflections of my PhD journey 2010-16. Learning Communities: International Journal of Learning in Social Contexts [Special Issue: Decolonising Research Practices] , 22, 38-47.

Mackenzie, N. M., \& Lorraine , M. L. (2009). The research journey: A lonely planet approach. Issues in Educational Research , 19(1).

McCotter, S. S. (2001). The journey of a beginning researcher. The qualitative report.

McCulloch, A. (2013). The quest for the PhD: a better metaphor for doctoral education. International Journal for Researcher Development, 4, 55-66.

Merriam, S. B. (2009). Qualitative research in practice: Examples for discussion and analysis. Jossey-Bass.

Murphy, N. A., \& Wibberley, C. (2016). Development of an academic identity through PhD supervision- an issue for debate. Nurse Education in Practice .

Propp, V. (1979). Morfology of the folktale. Seventh Paperback Printing.

Randles, C. (2012). The "Hero's journey": A way of viewing music teacher socialization. Journal of Music Teacher Education, , 22(1), 11-19.

Retnaningdyah, P. (2015). 'We have voices, too': Literacy, alternative modernities and indonesian domestic workers in Hong Kong. Melbourne: The University of Melbourne.

Seary, K., \& Willans, J. (2004). It's more than just academic essays and rules of mathematics: Travelling the road with heroes on the STEPS journey as they convert the milestones of their learning journey into signposts for their future . Australian Journal of Adult Learning , 44(3), 306-326.

Trafford, V., \& Leshem, S. (2009). Doctorateness as a threshold concept. Innovations in Education and Teaching International , 46 (3), 305-316.

Vogler, C. (2007). The Writers journey: Mythic structure for writers, 3rd Edition. Studio City,: CA: Michael Wiese Productions.

Wellington, J. J. (2010). Making supervision work for you: a student guide. London: Sage.

Wilson, S. (2008). Research is ceremony: Indigenous research methods. Black Point, N.S.: Fernwood. 